\title{
MONETARY POLICY, DEBT AND THE CYCLICAL BEHAVIOR OF INVENTORIES
}

\author{
Abdul Ghafar b. Ismail \\ Zakariab. Bahari
}

\begin{abstract}
An earlier study on the determinants of inventories investment has been proposed by Lovel (1961). However, the study fails to mention the effects of financial variables. The puzzle prevails on account of imperfect capital markets. This implies that interest rate generally affects inventory investment indirectly through the debt channel. For instance, in the period of tight monetary policy, increasing interestrates have a negative impact on the present value of firms' collateralizable net worth. In addition, they also weaken firms' balance sheets as interest expenses also rise up. In imperfect capital markets, this fact indicates an increase in the amount of external financing that firms need, a rise in the premium on external financing that they face, and a reduction in their accumulation of assets, their spending and their production. Given the low adjustment cost that characterizes firms, it will be inventories that firms will initially reduce. Therefore, this paper is contributes to the issue of monetary policy transmission in Malaysia. Our specific attention is limited to the channel of monetary policy on a firm's inventory. Using micro data, we try to take into account the relevance of the firm's balance sheet conditions in the transmission of monetary policy.
\end{abstract}

Keywords: capital structure; inventories; monetary policy

JEL classification: E52; G32 


\section{Introduction}

The transmission of monetary policy on economic activities at macrolevel has been explored since the works of Gurley and Shaw (1955), Goldsmith (1969), and McKinnon (1973). They examined the ability of financial intermediaries to manage and allocate funds to potential firms. By receiving funds from surplus units, financial intermediaries can improve the efficiency of fund allocation, and help reduce liquidity problems. This improvement can be an important factor to generate economic activities. Subsequently, these studies have been extended to cover various issues that can be grouped into three main issues: financial intermediation and economic growth (for instances, King and Levine (1993a, 1993b), Levine and Zervos (1998), Holmstorm and Tirole (1997)); monetary policy and real variables [for instances, Romer and Romer (1989, 1991), Kasyap et al. (1993), Cooley and Quadrini (1999), and Chatelain et al. (2001)); and financial indicators as the measurement of financial intermediation (for instances, King and Levine (1993a), Levine and Zervos (1998), Rousseau and Wachtel (1998), Levine et al. (2000)].

At micro-level, firms acquire funds through internal and external financing. Firms with no endowment or less tangible assets use bank debt as the external financing, and vice versa. Therefore, empirical studies in the U.S. and Europe, for examples, Kashyap et al. (1994), Oliner and Rudebusch (1996), Siegfried (2000), and Chatelain et al. (2001) have greatly contributed to proving the debt channel of monetary transmission. Then, the question arises on how do the debt and monetary policy affect a firm's behavior? ${ }^{1}$

There are at least two answers which can be offered. First, the response of a firm to the impact of monetary policy can be detected from items in the firm's balance sheet, such as inventories, expected sales, and shortterm debt. It implies that the inventories item can be utilized to capture the lending view transmission mechanism. The presence of an adverse monetary shock affects the reduction in the net worth of firm's bank-dependent borrower; consequently, the firm has difficulties finding funds and hence reduces its economic activities earlier and more sharply than do other firms. The reduction in its economy activities operates largely through a decline in inventories investment.

Second, when firms borrow funds from banks and pay interest, the firms' balance sheets are exposed to monetary policy changes. An increase in interest rate directly weakens balance sheets by reducing cash flows (net of interest) and lowering the value of collateral assets. The impact can also be influential indirectly. The tight monetary policy may produce a decline in spending and subsequently, a decline

\footnotetext{
${ }^{1}$ We define behavior as reported in balance sheet.
} 
in cash flows and asset values. This initial decline in spending causes balance sheets of firms to deteriorate and, further, propagates the firms' activities.

The above answer has led several studies to identify the determinants of inventories investment. An earlier study on this subject was proposed by Lovel (1961). However, the study fails to mention the effects of financial variables. According to Browne, the puzzle exists due to imperfect capital markets. This implies that interest rate generally affects inventory investment indirectly through the credit channel. For instance, in the period of tight monetary policy, increasing interest rates have a negative impact on the present value of firms' collateralizable net worth. They also weaken firms' balance sheets by raising their interest expenses. In imperfect capital markets, this implies an increase in the amount of external financing that firms need, a rise in the premium on external financing that they face, and a reduction in their accumulation of assets, their spending and their production. Given the low adjustment cost that characterizes firms, it will be inventories that firms will initially reduce.

This article is a contribution to the issue of monetary policy transmission in Malaysia. We also provide empirical evidence of the firm-level finding in other areas outside U.S. and Europe. Our specific attention is limited to the channel of monetary policy on a firm's inventory. Using micro data, we try to take into account the relevance of the firm's balance sheet conditions in the transmission of monetary policy. The recourse to micro data is often motivated in the literature by the recognition of the limits of aggregate studies. For instance, Chirinko et al. (1999) find that the failure to find a significant relation between monetary policy shocks and target variables. ${ }^{2}$

The rest of this article is organized in the following way: the next section explains the theoretical background; the model used, data sources and estimation procedures are outlined in the third section; empirical results are examined in the fourth section; and the fifth section summarizes the conclusions.

\section{The Debt Channel of Monetary Transmission}

In the capital structure theory, firms use debt to gain some benefits and at the same time also bring financial distress. ${ }^{3}$ However, debt is important to predict certain components of economic activity even after allowing for interest rate changes and other factors (including collateral and cash flows). These changes are necessary to

\footnotetext{
${ }^{2}$ This failure could be due to biased estimates triggered by problems of simultaneity, capital market frictions or firm heterogeneity that may be better addressed with micro data.

${ }^{3}$ For instance, the study on the benefits of tax on debt and cost of debts are mentioned by MacKie-Mason (1990) and Asquith, Gertner and Charfstein (1994), respectively.
} 
Gadjah Mada International Journal of Business, January - April 2007, Vol. 9, No. 1

address the issue of lending as the channel of monetary transmission. Therefore, when firms borrow funds from banks and pay interest, firms are exposed to monetary policy changes. Hence, a question arises on how do we relate the firms' behavior and monetary policy? ${ }^{4}$

There are two complementary ways of explaining about how firms might be influenced by the changes in monetary policy, i.e., through the balance sheet channel and the bank lending channel.

\section{The Balance Sheet Channel}

The theory of business cycle or 'the balance sheets channel' emphasizes the role of a firm's balance sheet. This theory, amongst others, is propagated by Bernanke and Gertler (1989), Calomiris and Hubbard (1990), Gertler (1992), Kiyotaki and Moore (1993), Gertler and Gilchrist (1994), Cooley and Quadrini (1999), and Leo de Haan and Elmer (2000). With an assumption of capital market imperfection, the basic idea in this theory is focused on the spending of firms which depends on their balance sheets position, related to the value of collateralizable net worth and the credit terms. This leads directly to a financial propagation mechanism: swings in balance sheets over the cycle amplify swings in spending.
The pioneering work of Bernanke and Gertler (1989) produces the relationship between the condition of a firm's balance sheet and output fluctuations. They develop a simple neoclassical model of the business cycle in which the condition of a firm's balance sheet is a source of output fluctuations. The firm's net worth is an important item to assess the position of the firm's balance sheet. The higher the firm's net worth, the stronger the position of the firm's balance sheet, and viceversa. However, when there is asymmetric information between the firm and bank, it increases the agency costs. It implies that external funds are more costly compared to internal funds. Furthermore, the greater the level of net worth, the lower will be the expected agency costs. Consequently, when the firm's net worth is low, the agency costs in investment are relatively high. Two main implications can be derived. First, the level of firm's net worth seems to be pro-cyclical, i.e., the firm is more solvent in the period of good time. The agency costs are expected to decline and increase in boom and recession periods, respectively. Second, shocks to the firm's net worth occurring independently of aggregate output would be an initiating source of real fluctuations. ${ }^{5}$

Gertler (1992) extended the above study with the multi-period contract-

\footnotetext{
4 For instance, the capital structure and inventory decisions (as part of a firm's behaviour) may also be translated in the balance sheet.

${ }^{5}$ The fall in unanticipated price level can cause a decline in entrepreneur's net worth. Hence, the higher will be the agency costs associated with lending, thereby reducing investments.
} 
ing model of financial propagation mechanism. The model emphasizes the roles of a firm's financial assets (internal funds) in reducing the agency costs of investment, and generating expected profit. This expected profit could increase the collateral value. As a result, small but persistent shifts in macroeconomic fundamentals may induce large fluctuations in credit constraints and this, in turn, is transmitted into potentially large fluctuations in output.

The aim to obtain evidence of the financial propagation mechanism for aggregate data is reported by Gertler and Gilchrist (1994). Using the sample of small and large firms, they tried to analyze the different responses of both firms to monetary policy in boom and recession periods. They used the Romer dates episode (Romer and Romer 1989) and the 1966 credit crunch as proxies for the shifts to tight money policy. The responses of firms to the impact of tight money can be detected from the items in their balance sheets, such as inventories, expected sales, and shortterm debt. They find that monetary policy shocks have a greater cumulative impact on small firms than on large firms. For small firms, inventories, short-term debt, and sales drop rapidly in the wake of tight money policy. Meanwhile, for large firms, inventories, short-term debt, and sales decline slowly. They conclude that small firms are much sensitive to monetary policy shocks than are large firms.
Other empirical evidence, such as that of Cooley and Quadrini (1999), is also applied at firm level. They developed a general equilibrium model with heterogeneous and long-lived firms. They also tried to prove that financial factors play an important role in firms' production and investment decisions. In their model, they show that small firms with less net worth (equity) depend heavily on debt, and the changes in lending rate reduce the firms' profits, which in turn decrease their nextperiod equities. This implies that firms borrow less in the next period and, consequently, affect their production and investments compared with large firms with high net worth and ease to access funds in the capital market.

Recent studies in monetary theory, such as Leo de Haan and Elmer (2000), show that it is important to analyze the difference in the impacts of monetary policy on various types and classes of firms, and moreover on various balance sheet items. They indicate that small firms are more likely to be faced with high external financing. Therefore, it is important to analyze the influence of monetary policy on various types of firms' capital structures and balance sheets. In addition, the impact of monetary channel on the behavior of banks and corporate decisions seems relevant since corporate decisions have a large impact on business fluctuations. Using the sample of a half million European firms, they analyzed the influence of monetary 
contraction on leverage, financial debt, and loans. They find that these financial indicators decline after monetary shocks.

Therefore, monetary policy influences both directly and indirectly on firms' spending. An increase in interest rate directly weakens balance sheets by reducing cash flows (net of interest) and lowering the values of collateral assets. The impact can also influence indirectly. The tight monetary policy may produce a decline in spending, and subsequently, a decline in cash flows and asset values. This initial decline in spending causes balance sheets of firms to deteriorate and, further, propagates the economic downturn.

\section{The Lending Channel}

The theory of "credit" and "lending" views or "the bank lending channel" stresses the ability of monetary policy to regulate the pool of funds available to bank-dependent firms, owing to the presence of legal reserve requirements on bank deposits. Amongst the authors who introduced this theory are Romer and Romer (1991), Fuerst (1992), Bernanke and Blinder (1992), Kasyap et al. (1993), Kashyap et al. (1994), Oliner and Rudebusch (1996), Siegfried (2000), and Chatelain et al. (2001).

The lending channel was introduced by Romer and Romer (1991), developed based on their previous study (1989), and looked at the impacts of monetary shocks on real variables, such as output and unemployment rate. ${ }^{6}$ They explain those impacts through the new monetary transmission, i.e., 'money view' and 'lending view'. According to 'money view' transmission mechanism, the reduction in reserves raises interest rate since it implies a fall in transaction deposits. It shows the special characteristics of the liability side of banks' balance sheets.

In 'lending view', the reduction in the stock of reserves reduces the quantity of loans because the scarce reserves force banks to bid up interest rate to the depositors and this, in turn, raises interest rate. ${ }^{7}$ Over time, as mentioned by Bernanke and Blinder (1992), the brunt of tight money forces bank to terminate old loans and refuses to provide new debt. Therefore, the tight monetary policy has a direct impact on bank lending. Hence, the change in monetary policy leads to declining real sector. However, imperfect credit market may also cause borrowers to search for alternative sources of funds. Here, there is no evidence for monetary transmission mechanism through lending channel. Based on these results, we can conclude that monetary policy has little effect on bank lending.

Later, Fuerst (1992) offers a somewhat related analysis on lending view based on "liquidity effect" approach.

\footnotetext{
6 These studies extend the "narrative approach" constructed by Friedmen and Stiglitz (1963).

7 The same argument can also be seen in Bernanke and Blinder (1992).
} 
The central bank controls the liquidity in the market by injecting new cash (as lender of the last resort), and this can increase the quantity of debt provided by banks. Consequently, the injection of cash can render the nominal interest rate falling, and benefit firms by increasing current and future production.

The effect of monetary policy on bank lending can also be observed through the effect on a firm's capital structure, as suggested by Kashyap, Stein, and Wilcock (1993). This study takes the Romer episodes and credit crunch as the indicators of monetary policy shocks. ${ }^{8}$ They suggest that the credit rationing may cause a decline in the supply of loans, and the interest rate increases consequently. The later affects the firm' $s$ cash flows, and pushes down asset prices and weakens the firm's balance sheet. Holmstrom and Tirole (1997) further argue that this phenomenon pushes loan losses and lowers asset prices. Hence, it significantly eats the equity of banks and causes banks to pull back on their lending and to increase interest rate spreads. Subsequently, credit crunch hits weak collateral of small firms the hardest and bank-dependent borrowers.

When the tight monetary policy is implemented, the commercial paper issuance rises whilst bank loans fall. In this regard, Kashyap et al. (1993) in- vestigated the movements in financing variables such as bank loans, commercial papers, mixed of commercial papers and bank loans, and commercial papers to Treasury bill. The study tried to provide evidence of the existence of a loan supply channel of monetary policy transmission. They used the Roomer dates, the credit crunch of 1966, and interest rate as the indicators of the stance of monetary policy. They find that a decline in the mixed variables indicates that the reduction in loan supply affects investments, especially to the bank-dependant entrepreneurs. In addition to examining the responses of firms to bank lending condition, they augment a standard inventory model with mixed variables. They discover that mixed variables are economically and statistically significant. Therefore, their results suggest that information on the state of bank loan supply does a better job in explaining inventory movements compared to does the open-market interest rate. They also interpret that the monetary policy has an important effect on bank lending condition, and firms do not access external funds as the public market has more sensitive inventory investments to bank lending. They conclude that in order for the monetary policy to affect the economy through a lending channel, banks must firstly view debt and securities as imperfect substitutes for the assets side of their

\footnotetext{
${ }^{8}$ Banks have to ration debt to potential entrepreneurs to avoid high risk and return projects. The rationing of entrepreneurs leads to credit crunch. In the United States, it happenned in 1966 and 1990-1991.
} 
balance sheets. Second, in liabilities side of their balance sheets, debt and nonbank sources of financing are also imperfect substitutes.

Therefore, current studies on monetary transmission have been applied at firm level, see for examples, Kashyap et al. (1994), Oliner and Rudebusch (1996), Siegfried (2000) and Chatelain, et al. (2001). They utilized inventories to capture the lending view transmission mechanism. We expect the inventories of bank-dependent firms to fall more sharply in response to a monetary contraction than the inventories of firms which do not rely on bank debt. Using firm-level inventory data, Kashyap, Stein, and Lamont (1994), constructed an inventory equation to examine the effect of monetary policy on the liquidity of firms. They fixed three episodes indicating the changes in monetary policy, i.e., the period of 1974-1975 as tight monetary policy; the recession period of 19811982; and the loose policy period of 1985-1986. They find that the first and second episodes only affect firms with less access to external financing in the public market. At the same time, in the second episode, the bank loan supply also declines. Although the results are consistent with the prediction of lending view, but they are still not clear on how sharp they can distinguish lending view from other variables in the imperfect capital market. An example for the later is the recession causes the decline in collateral values, thereby increasing the cost of bank financing.

Another study by Oliner and Rudebusch (1996) tried to improve the Kashyap-Stein-Wilcock model by widening the definition of financial variables to include trade financing plus commercial papers as debt from nonbank sector, and using firm-level data. They find that small firms could not increase the use of trade credit during the period of tight money. This finding is consistent with Gertler and Gilchrist (1994).

Most of the above studies harnessed U.S. data to prove the lending view channel of monetary transmission. Other studies such as Siegfried (2000) and Chatelain et al. (2001) applied European countries data. Both writers used disaggregate firm-level data to examine interest channel and credit channel in monetary transmission mechanism as the implication of changes in monetary policy towards capital structure decisions of the firms. ${ }^{9}$ Chatelain et al. (2001) find that investment is sensitive to user cost changes in Germany, Italy, France, and Spain after monetary shocks. The user cost changes happen within the first two years. This implies that the interest channel works in these countries. Only in Italy, smaller firms react more to cash flow movements compared to large firms do, suggesting that a credit channel might not be pervasive in all countries.

\footnotetext{
${ }^{9}$ The traditional view focuses on the changes in interest rate leading to the changes in the cost of capital, and consequently affect investment.
} 
Ismail \& Bahari-Monetary Policy, Debt and the Cyclical Behavior of Inventories

In contrast, the study done by Siegfred (2000) finds that interest rate channel seems to be of little importance to investment decisions of firms in Germany. The results show that the credit channel is dominant in Germany. The firms also suffer credit constraints only in some periods of tight monetary policy.

Basically, in the lending view, there are three assets: money, publicly issued bonds, and intermediated "loans," which will work in the transmission mechanism. In this view, the banking sector can now be special in addition to creating money and makes loans. Monetary policy can work not only through its impact on the bondmarket rate of interest and the supply of intermediated loans. For example, the decrease in reserves can have important real consequences if it leads banks to cut back on loan supply: the cost of loans relative to bond will rise, and those firms, which are dependent entrepreneurs, will be led to cut back on investment. Therefore, the monetary policy can have significant real effects that are not summarized by its consequences for open-market interest rate. Those studies also find that the frequent increases in the market interest rate will depress firms' investments and also increase the firms' interest rates through the balance sheet channel, and will persistently decrease the firms' investments. This will harder affect firms with high debt.

\section{Research Method}

Recent studies in monetary theory show that it is important to analyze the different impacts of monetary policy on various types and classes of firms, and moreover on various balance sheet items. Therefore, it is important to analyze the influence of monetary policy on inventory and balance sheets of various types of firms. In addition, the impact of monetary channel on the behavior of banks and corporate decisions seems to be relevant since corporate decisions have a large impact on business fluctuations. Using these findings, the discussion in this section will be focused on research design, including theoretical models, data sources, and description and estimation procedures.

\section{Theoretical Models}

The findings above show that the inventory equation is able to capture both lending and balance sheet views of transmission mechanism. In addition, Chikan and Horvath (1999) believe that inventory is known as the indicators and devices of short-term adaptation, both at individual-firmlevel and at macro level. Its movement is expected to be a major source of fluctuation in gross national product. Therefore, inventories could stabilize the macroeconomic variables. Besides, the construction of inventory model is not only used to better understand the 
Gadjah Mada International Journal of Business, January - April 2007, Vol. 9, No. 1

macroeconomics of business cycles, but also the microeconomics of the firms especially the effect of debt and inventories investment of the firms.

There have been many studies trying to examine the inventory behavior, such as Lovel (1961), Blinder and Maccini (1991), Kashyap, Stein, and Lamont (1994), Kashyap et al. (1993), Gertler and Gilchrist (1994), and Louri (1996). The concentration of these studies can be divided into three main issues: (a) the factors that determine the inventory behavior, see for example Lovel (1991); (b) the inventory behavior as a result of monetary policy changes, see for example Gertler and Gilchrist (1994), Kashyap et al. (1993), and Kashyap et al. (1994); and (c) the econometric issues in estimating the inventory model, see for example Blinder and Maccini (1991). These studies also show that inventory movement is a dominant feature of business cycle as mentioned by Blinder and Maccini (1991).

To specify the models, first, we adopt the inventory equation used by Kashyap et al. (1993) as our starting point to construct the desired inventory equation. The desired inventory equation is specified as follows:

$$
\mathrm{I}_{\mathrm{t}}^{\mathrm{d}}=\mathrm{a}_{0}+\mathrm{a}_{1} \mathrm{~S}_{\mathrm{t}}^{*}+\mathrm{u}_{1 \mathrm{t}}
$$

Equation (1) shows that the desired inventories $\left(\mathrm{I}^{\mathrm{d}}\right)$ are determined by several factors. We identify the

sales variable $\left(\mathrm{S}^{*}\right)$ as an indicator of firm's activity over time as we cannot construct the exact output in the firm's balance sheet.

Second, to examine the partial realization of desired inventory, Equation (1) should be modified by the following steps. We assume that, each period, the firm eliminates only a fraction of the difference between desired $\left(\mathrm{I}^{\mathrm{d}}\right)$ and inherited inventory levels $\left(\mathrm{I}^{\mathrm{i}}\right){ }^{10}$

$$
\Delta \mathrm{I}_{\mathrm{t}}^{\mathrm{p}}=\lambda\left(\mathrm{I}_{\mathrm{t}}^{\mathrm{d}}-\mathrm{I}_{\mathrm{t}-1}^{\mathrm{i}}\right)
$$

where $\left(\Delta \mathrm{I}^{\mathrm{p}}\right)$ is the change in inventories planned for current period, 1 is the speed of adjustment, and $I^{i}$ is inventories held at the end of period consisting of inventories inherited from the previous period. In addition, due to overoptimistic or overpessimistic forecast that leads to higher or lower production than that actually required, the firm may end up with unintended changes in inventories $\left(\Delta \mathrm{I}^{\mathrm{u}}\right)$. The unintended changes in inventories are measured by the difference between actual output and actual demand that may pile up or down as "buffer" inventories. By approximating the actual demand by current sales, $S$, and the actual output by the index of industrial production, $Q$, the equation for $\Delta I^{u}$ can be written as:

$$
\left(\Delta \mathrm{I}_{\mathrm{t}}^{\mathrm{u}}\right)=\mathrm{b}_{0}+\mathrm{b}_{1} \mathrm{~S}_{\mathrm{t}}+\mathrm{b}_{2} \mathrm{Q}_{\mathrm{t}}
$$

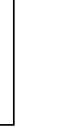

${ }^{10}$ We also call this equation "accelerator" or stock adjustment

${ }^{10}$ We also call this equation "accelerator" or stock adjustment model.
(1993) dan Gentler and Gilchrist (1994) also consider this adjustment. 
From the definition of actual inventories that consist of inventories inherited, changes in inventories planned, and unintended changes in inventories, we can write the equation for the actual inventories as:

$$
\mathrm{I}_{\mathrm{t}}=\mathrm{I}_{\mathrm{t}-1}^{\mathrm{i}}+\Delta \mathrm{I}_{\mathrm{t}}^{\mathrm{p}}+\Delta \mathrm{I}_{\mathrm{t}}^{\mathrm{u}}
$$

By subtracting both sides with $I_{t-1}^{i}$ and substituting Equation (3) into Equation (4), we have:

$$
\begin{aligned}
\mathrm{I}_{\mathrm{t}}-\mathrm{I}_{\mathrm{t}-1}^{\mathrm{i}}= & \mathrm{I}_{\mathrm{t}-1}^{\mathrm{i}}-\mathrm{I}_{\mathrm{t}-1}^{\mathrm{i}}+\lambda\left(\mathrm{I}_{\mathrm{t}}^{\mathrm{d}}-\mathrm{I}_{\mathrm{t}-1}^{\mathrm{i}}\right)+ \\
& \mathrm{b}_{0}+\left(\mathrm{b}_{1} \mathrm{~S}_{\mathrm{t}}+\mathrm{b}_{2} \mathrm{Q}_{\mathrm{t}}\right) \ldots \ldots \ldots \ldots
\end{aligned}
$$

Then, Equation (5) can be rewritten as:

$$
\begin{aligned}
\Delta I_{t}= & \lambda\left(I_{t}^{d}-I_{t-1}^{i}\right)+b_{0}+ \\
& \left(b_{1} S_{t}+b_{2} Q_{t}\right) \ldots \ldots \ldots . . .
\end{aligned}
$$

Inserting Equation (1) into Equation (5), and rearranging the constant, explanatory variables, and error term, we have the following equation:

$$
\begin{aligned}
\Delta \mathrm{I}_{\mathrm{t}}= & \left(\lambda \mathrm{a}+\mathrm{b}_{0}\right)+\lambda \mathrm{a}_{1} \mathrm{~S}_{\mathrm{t}}^{*}+\lambda \mathrm{I}_{\mathrm{t}-1}^{\mathrm{i}}+ \\
& \mathrm{b}_{2} \mathrm{Q}_{\mathrm{t}}+\mathrm{b}_{1} \mathrm{~S}_{\mathrm{t}}+\mathrm{u}_{2 \mathrm{t}} \cdots \ldots \ldots \ldots \ldots \ldots
\end{aligned}
$$

and $\mathrm{m}_{1 \mathrm{t}}$ is the error term.

Equation (7) explains that the changes in inventory are influenced by expected sales, lagged inventory, out- put and sales. The expected sales, and output and sales 'surprises' are positively related to the changes in inventory. The cost of carry (CR) is an important determinant; as financing becomes more expensive, firms cut back on their inventory holdings. ${ }^{11}$ The impact of monetary policy is transmitted through the cost of financing channel. Hence, we augment the inventory equation with carrying cost such as coverage ratio, and interest rate. These variables are negatively related to the changes in inventory.

$$
\begin{aligned}
\Delta \mathrm{I}_{\mathrm{it}}= & \left(\lambda \mathrm{a}+\mathrm{b}_{0}\right)+\lambda \mathrm{a}_{1} \mathrm{~S}_{\mathrm{it}}{ }^{*}+ \\
& \mathrm{c}_{1} C O_{\mathrm{it}}+\mathrm{c}_{1} \mathrm{i}_{\mathrm{it}}+\lambda \mathrm{I}_{\mathrm{it}-1}^{\mathrm{i}}+ \\
& \mathrm{b}_{2} \mathrm{Q}_{\mathrm{it}}+\mathrm{b}_{1} \mathrm{~S}_{\mathrm{it}}+\mathrm{u}_{2 \mathrm{t}} \cdots \cdots \cdots \cdots
\end{aligned}
$$

However, we specify that the expected values of sales and carrying cost follow certain distributed lags. Hence, Equation (8) can be rewritten as:

$$
\begin{aligned}
\Delta \mathrm{I}_{\mathrm{it}}= & \mu_{0}+\mu_{1} \mathrm{~S}_{\mathrm{it}-1} *+ \\
& \mu_{2} C O_{\mathrm{it}-1}+\mu_{3} \mathrm{i}_{\mathrm{it}-1}+\lambda \mathrm{I}_{\mathrm{it}-1}^{\mathrm{i}}+ \\
& \mathrm{b}_{2} \mathrm{Q}_{\mathrm{it}}+\mathrm{b}_{1} \mathrm{~S}_{\mathrm{it}}+\mathrm{u}_{2 \mathrm{t}} \ldots \ldots \ldots \ldots \ldots \ldots
\end{aligned}
$$

where, $\mu_{0}=\left(\lambda \mathrm{a}+\mathrm{b}_{0}\right) ; \mu_{1}=\lambda \mathrm{a}_{1} ; \mu_{2}=\mathrm{c}_{1}$; $\mu_{3}=c_{2}$; and $\Delta \mathrm{I}$ is growth rate of inventories. The first two terms reflect the influence of the long-run target of inventory level. The long-run target of inventory level depends on the ex-

\footnotetext{
${ }^{11}$ Some authors like Kashyap et al. (1994) identify the interest expense as a proxy for carrying cost.
} 
pected sales and carrying cost (as proxies for movements in firms' overall financial positions).

We try to modify Equation (9) by adding two elements. First, Equation (9) imposes therestriction that thelongrun inventory/sales ratio (IS) is constant, conditional on the coverage ratio and the interest rate. However, since the components of the carrying cost comprise the coverage ratio $(\mathrm{CO})$ and the interest rate $(i)$, the ratio of inventory over sales is no longer constant. Higher interest rate (or other monetary policy instruments/shocks) induces firms to reduce inventories.

Second, we also include the lagged differences in each explanatory variable into the regression to capture any additional short-run dynamics. To do this, we have to add variables that capture the short-run dynamic relationship. By so doing, we try to see the structure of the long-run behavior of inventories, and allow the long-run target to influence the short-run growth. Output variable is not excluded since we cannot construct an exact output measure in firms' balance sheets over time.

Therefore, Equation (9) could be rewritten as:

$$
\begin{aligned}
\Delta \mathrm{I}_{\mathrm{it}}= & \mu_{0}+\mu_{1} \mathrm{~S}_{\mathrm{it}-1}{ }^{*}+\mu_{2} C O_{\mathrm{it}-1}+ \\
& \mu_{3} \mathrm{i}_{\mathrm{it}-1}+1 \Delta \mathrm{I}_{\mathrm{it}-1}^{\mathrm{i}}+\mathrm{b}_{1} \Delta \mathrm{S}_{\mathrm{it}-1}+ \\
& \mu_{4} \Delta C O_{\mathrm{it}-1}+\mu_{5} \Delta \mathrm{i}_{\mathrm{it}-1}+\mathrm{u}_{2 \mathrm{t}}
\end{aligned}
$$

Equation (10) provides us with the equation for inventory growth that we estimate.

\section{Data}

Firm-level data are collected from the CD ROM database of Kuala Lumpur Stock Exchange, a database containing the annual reports of all Malaysian stock-quoted firms. The firms are all distributed over all sectors of the economy, and the data run from 1995 to 2000 . We exclude financialrelated firms. To avoid dominating outliers, we delete firms with which any variable is in the upper or lower 0.1 percent of the dataset. This leaves us with unbalanced panel data of 345 firms. To see whether firms in the panel are credit constrained, we consider bankruptcies that occur during the sample period. We find that there is no firm going broke during the study period.

Toconstruct the indicators of monetary policy, we follow three approaches that have been suggested in the literature. First, the narrative approach (for instance, Romer and Romer (1989). We read Bank Negara Malaysia's annual reports and suggest that tight monetary policy (as indicated by the changes in required reserves requirement) prevailed in 1996, 1997, and 1998. The second approach, suggested by Bernanke and Blinder (1992), uses the interbank rate as a measure of monetary policy. Figure 1 demonstrates that the periods of tight 
Figure 1. Financial Indicators and Monetary Shocks

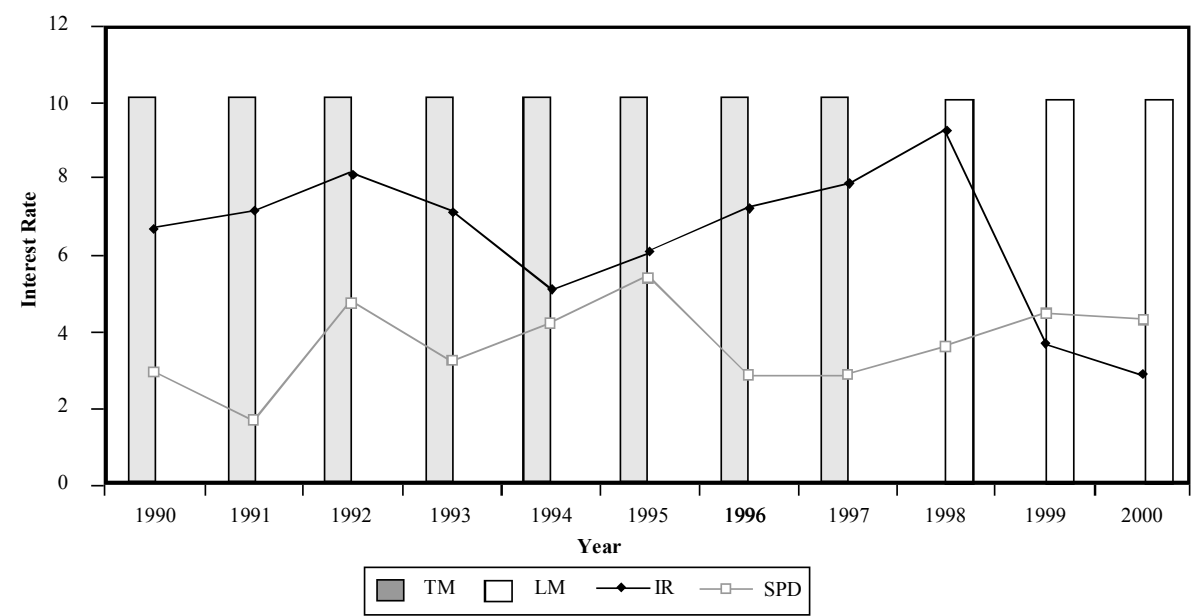

Note: TM is tight monetary policy, LM is loose monetary policy, IR is inter-bank rate and SPD is interest rate spread

monetary policy, identified by the narrative approach, are the same as those in which treasury bill rates increased sharply. Third, Laurant (1988) and Goodfriend (1991) support the use of spread between short- (deposit rate) and long-term rate (lending rate). In the lending channel, a rise in interest rate leaves riskier projects in the pool of financially viable projects, thereby increasing the monitoring costs of banks. The rise in banks' intermediation costs eventually requires higher spread, which reduces credit supply.

\section{Estimation Techniques}

In estimating Equation (10), there are some methodological issues in- volved. First, we estimate the model in first differences, as opposed to levels. It is interesting to observe the model of inventory in a continuous-time framework that allows firms to adjust their balance sheets to the changes in monetary policy. ${ }^{12}$ Second, we do not include other variables to control for firm-specific effects. These effects could be eliminated if we estimate the model in first differences. Moreover, the lagged endogenous variable takes the role of adjustment.

Since the estimation for Equation (10) utilizes panel data and is intertwined with individual firms, it is subject to the heterogeneity in these firms over time. In order to take such hetero-

\footnotetext{
${ }^{12}$ This dynamic-type capital structure might be motivated to get the benefits of debt financing (e.g., tax advantage), and reduce the potential costs of debt financing (e.g., bankruptcy costs and financial distress).
} 
geneity explicitly into account in our estimation procedures, several assumptions on the error term have to be made.

The intercept value for an individual firm is:

$$
\alpha_{0 i}=\alpha_{0}+u_{i 2}
$$

where $u_{i 2}$ is a random error term with a mean value of zero and variance of $\sigma^{2} u_{2}$. Substituting Equation (11) into Equation (10), we find that the error term consists of two components: $u_{i 2}$, which is the cross-section or individual specific error component, and $u_{i t}$, which is the combined time series and crosssection error component.

If the error terms of firms at two different points in time are correlated, the correlation coefficient, corr $\left(w_{i t}\right.$, $w_{i s}$ ), is as follows:

$$
\operatorname{Corr}\left(w_{i t}, w_{i s}\right)=\frac{\sigma^{2} u_{2}}{\sigma^{2} u_{2}+\sigma^{2} u_{1}}
$$

From Equation (12), two features of the correlation coefficient can be highlighted. First, the value of correlation between error terms at two different times remains the same for any given cross-section unit. Second, the correlation structure given in Equation (12) remains the same for all crosssection units. Hence, by employing OLS estimation procedure, the resulting estimators will be inefficient. Therefore, the most appropriatemethod is themethod of generalized least square
(GLS). At this point, however, the equations are linked by the disturbances.

To evaluate the model presented in Equation (10), we utilize several diagnostic tests: adj. $\mathrm{R}^{2}$ and $\mathrm{DW}$-statistics. The usual $\mathrm{R}^{2}$ often suggests that the fit of the model is improved by a correction for heteroscedasticity, and degraded by a correction for autocorrelation. A more appealing fit measure might be based on the residual from the original model. Moreover, this measure cannot be reliably used to compare between models.

\section{Empirical Results}

Table 1 presents some descriptive statistics for the eight variables, i.e., change in inventory (Panel A), sales (Panel B), coverage ratio (Panel C), cash flows (Panel D), interest expense (Panel E), short-term debt (Panel F), change in sales (Panel G), and change in coverage ratio $(\mathrm{Panel} \mathrm{H})$. Overall, as is usually the case with panel data, there is a wide dispersion of the variables employed in each sample. It can be seen that the means, sales, and coverage ratio are higher for large firms. Higher value of coverage ratio is due to higher cash flows compared to interest expense. The dispersion of these variables is also higher for large firms. As to other variables, it is interesting to note that, on average, the change in inventory, sales, and coverage ratio are higher for small firms than large firms. The dispersion is also higher for small firms. It reflects the volatility of those variables. 
Ismail \& Bahari-Monetary Policy, Debt and the Cyclical Behavior of Inventories

Table 1. Descriptive Statistics

\begin{tabular}{|c|c|c|c|}
\hline Variable & All samples & Small Firms & Large Firms \\
\hline \multicolumn{4}{|l|}{ Panel A: DI } \\
\hline Mean0.0857 & 0.2409 & 0.0857 & \\
\hline Standard Deviation & 1.1967 & 1.2177 & 0.1179 \\
\hline \multicolumn{4}{|l|}{ Panel B: Sale } \\
\hline Mean12.5758 & 11.0783 & 12.6885 & \\
\hline Standard Deviation & 1.2423 & 0.8604 & 1.3193 \\
\hline \multicolumn{4}{|l|}{ Panel C: Coverage ratio } \\
\hline Mean137.7960 & 128.9771 & 141.2280 & \\
\hline Standard Deviation & 1341.207 & 1272.205 & 1339.867 \\
\hline \multicolumn{4}{|l|}{ Panel D: Cash flow } \\
\hline Mean 10.3648 & 8.7271 & 10.49430 & \\
\hline Standard Deviation & 1.4885 & 1.3182 & 1.5313 \\
\hline \multicolumn{4}{|l|}{ Panel $\boldsymbol{E}:$ Interest expenses } \\
\hline Mean8.6944 & 7.0579 & 8.8304 & \\
\hline Standard Deviation & 1.8996 & 1.6630 & 1.9579 \\
\hline \multicolumn{4}{|l|}{ Panel F: Short-term debt } \\
\hline Mean10.7950 & 9.4461 & 10.9114 & \\
\hline Standard Deviation & 2.0526 & 0.7417 & 2.1273 \\
\hline \multicolumn{4}{|l|}{ Panel G: Change in sale } \\
\hline Mean0.0936 & 0.1119 & 0.0910 & \\
\hline Standard Deviation & 0.7607 & 0.8850 & 0.8118 \\
\hline \multicolumn{4}{|l|}{ Panel H: Change in CR } \\
\hline Mean-34.84324 & 42.6127 & -30.0184 & \\
\hline Standard Deviation & 1442.083 & 3331.102 & 1566.306 \\
\hline
\end{tabular}

The results, obtained from the estimation of Equation (12) when the total sample is split into three: small firms (column 2), large firms (column 3 ), and all firms (column 4), are reported in Table 2. The coefficient of the coverage ratio is not significant for three different sample categories. Focusing on the effect of monetary policy, we see that the $T M_{t-1}$ has a coefficient of -0.2126 for small firms, whilst the coefficients for large and all firms are 
Gadjah Mada International Journal of Business, January - April 2007, Vol. 9, No. 1

Table 2. Inventory Equation with Narrative Approach

\begin{tabular}{|c|c|c|c|}
\hline \multirow{2}{*}{$\begin{array}{c}\text { Dependent } \\
\text { variable: } \\
\Delta \mathbf{I}_{\mathrm{it}}\end{array}$} & \multicolumn{3}{|c|}{ Sample } \\
\hline & Small Firms & Large Firms & All Firms \\
\hline Constant & $0.9163(3.3767)^{*}$ & $0.5014(3.6839)^{*}$ & $0.6269(5.7700)^{*}$ \\
\hline $\mathrm{S}_{\mathrm{it}-1}$ & $-0.0489(2.0807)^{* *}$ & $-0.0515(4.9671)^{*}$ & $-0.0577(6.9257)^{*}$ \\
\hline $\mathrm{CR}_{\mathrm{it}-1}$ & $1.53 \mathrm{E}-05(0.5361)$ & $1.46 \mathrm{E}-05(1.4238)$ & $1.25 \mathrm{E}-05(1.4725)$ \\
\hline $\mathrm{TM}_{\mathrm{it}-1}$ & $-0.2126(2.6468)^{*}$ & $0.3565(11.1226)^{*}$ & $0.2953(11.7389)^{*}$ \\
\hline $\mathrm{DI}_{\mathrm{it}-1}$ & $-0.4175(6.2035)^{*}$ & $-0.2072(7.9411)^{*}$ & $-0.2089(9.9583)^{*}$ \\
\hline $\mathrm{DS}_{\mathrm{it}-1}$ & $-0.2671(4.4267) *$ & $0.0072(0.2904)$ & $0.0210(1.0113)$ \\
\hline $\mathrm{DCR}_{\mathrm{it}-1}$ & $3.14 \mathrm{E}-06(0.2556)$ & $-1.00 \mathrm{E}-06(0.1223)$ & $1.86 \mathrm{E}-06(0.2751)$ \\
\hline DTM $_{\text {it-1 }}$ & $0.5054(5.1657)^{*}$ & $-0.1794(4.5337)^{*}$ & $-0.1190(3.8864)^{*}$ \\
\hline $\mathrm{R}^{2}$ & 0.8881 & 0.9653 & 0.9867 \\
\hline
\end{tabular}

Note: a. $*, * *$ and $* * *$ are significant at 1 percent, 5 percent and 10 percent levels, respectively

b. The figures in parentheses are absolute t-value

0.3565 and 0.2953 , respectively (columns (3) and (4)). These results show that firms are generally more sensitive to variation in the monetary policy than the coverage ratio.

To check the robustness of our results, at this point, we adopt two alternative estimations, $I R_{t-1}$ and $S P D_{t}$ ${ }_{1}$ as shown in Tables 3 and 4 . The first estimation can be interpreted as: the effect of monetary policy should have its strongest influence on short-term interest rate (i.e., interbankrate). Meanwhile, the second estimation describes the effect of monetary policy actions on the supply of loans by banks and, consequently, spending for durable goods such as inventories. Column 4 of Table 3 and column 3 of Table 3 deal with all firms and large firms, respectively. We can see that the coverage ratio has coefficients of 1.94E-05 and $1.62 \mathrm{E}-05$ for all firms and large firms, respectively, whilst the corresponding figure for small firms is not significant. Similar findings are also reported in column 4 of Table 4 and column 3 of Table 4 . The coverage ratio affects inventories investment of large firms more significantly than that of small firms. This is not surprising since in fact, small firms have been generally characterized by high cash flows. Consequently, the collateral value of large firms' future cash receipt increases, causing a decline in the cost of external financing and an increase in the firms' access to it. In this situation, an in- 
Ismail \& Bahari-Monetary Policy, Debt and the Cyclical Behavior of Inventories

Table 3. Inventory Equation with Inter-bank Rate

\begin{tabular}{|c|c|c|c|}
\hline \multirow{2}{*}{$\begin{array}{c}\text { Dependent } \\
\text { variable: } \\
\quad \Delta \mathbf{I}_{\mathrm{it}}\end{array}$} & \multicolumn{3}{|c|}{ Sample } \\
\hline & Small Firms & Large Firms & All Firms \\
\hline Constant & $1.1633(3.5999) *$ & $0.7274(4.7406)^{*}$ & $0.9604(8.2695)^{*}$ \\
\hline$S_{i t-1}$ & $-0.0584(2.2404)^{* *}$ & $-0.0742(6.9608)^{*}$ & $-0.0772(9.3538)^{*}$ \\
\hline $\mathrm{CR}_{\mathrm{it}-1}$ & 2.29E-05(0.9636) & $1.94 \mathrm{E}-05(1.9661)^{* *}$ & $1.62 \mathrm{E}-05(2.0128)^{* *}$ \\
\hline $\mathrm{IR}_{\mathrm{it}-1}$ & $-0.0587(2.5578)^{*}$ & $0.0480(4.4813)^{*}$ & $0.0189(2.3463)^{* *}$ \\
\hline $\mathrm{DI}_{\mathrm{it}-1}$ & $-0.3861(5.9782)^{*}$ & $-0.1932(7.3409) *$ & $-0.1989(9.4907)^{*}$ \\
\hline $\mathrm{DS}_{\mathrm{it}-1}$ & $-0.2771(4.6367)^{*}$ & $0.0417(1.6408)^{* * *}$ & $0.0544(2.5722)^{*}$ \\
\hline $\mathrm{DCR}_{\mathrm{it}-1}$ & $1.59 \mathrm{E}-07(0.0124)$ & $-1.67 \mathrm{E}-06(0.2084)$ & $2.055-06(0.3167)$ \\
\hline $\mathrm{DIR}_{\mathrm{it}-1}$ & $-0.0262(0.9356)^{* *}$ & $-0.0384(4.3130)^{*}$ & $-0.0199(2.9925)^{*}$ \\
\hline $\mathrm{R}^{2}$ & 0.7619 & 0.9751 & 0.9964 \\
\hline
\end{tabular}

Table 4. Inventory Equation with Interest Rate Spread

\begin{tabular}{|c|c|c|c|}
\hline \multirow{2}{*}{$\begin{array}{c}\text { Dependent } \\
\text { variable: } \\
\Delta \mathbf{I}_{\text {it }}\end{array}$} & \multicolumn{3}{|c|}{ Sample } \\
\hline & Small Firms & Large Firms & All Firms \\
\hline Constant & $0.5009(1.8863)^{* * *}$ & $0.8816(6.9472)^{*}$ & $0.9057(9.1791)^{*}$ \\
\hline $\mathrm{S}_{\mathrm{it}-1}$ & $-0.0554(2.4944)^{* *}$ & $-0.0686(-7.4334)^{*}$ & $-0.0727(10.0891)^{*}$ \\
\hline $\mathrm{CR}_{\mathrm{it}-1}$ & $1.91 \mathrm{E}-05(1.0784)$ & $1.69 \mathrm{E}-05(2.1554)^{* *}$ & $1.36 \mathrm{E}-05(2.1030)^{* *}$ \\
\hline $\mathrm{SPD}_{\mathrm{it}-1}$ & $0.0700(2.9821)^{*}$ & $0.0289(2.3760)^{* *}$ & $0.0354(3.8595)^{*}$ \\
\hline $\mathrm{DI}_{\mathrm{it}-1}$ & $-0.3452(5.9204)^{*}$ & $-0.1957(7.8720)^{*}$ & $-0.2018(10.0305)^{*}$ \\
\hline $\mathrm{DS}_{\mathrm{it}-1}$ & $-0.2089(3.7492)^{*}$ & $0.0454(1.8845)^{*}$ & $0.0608(3.0717)^{*}$ \\
\hline $\mathrm{DCR}_{\mathrm{it}-1}$ & $-2.20 \mathrm{E}-06(0.2223)$ & $4.15 \mathrm{E}-07(0.0682)$ & $3.78 \mathrm{E}-06(0.7680)$ \\
\hline $\operatorname{DSPD}_{\mathrm{it}-1}$ & $-0.0527(3.3976)^{*}$ & $-0.0266(3.4476)^{*}$ & $-0.0312(5.2893)^{*}$ \\
\hline $\mathrm{R}^{2}$ & 0.8988 & 0.9797 & 0.9906 \\
\hline
\end{tabular}


Gadjah Mada International Journal of Business, January - April 2007, Vol. 9, No. 1

crease (decline) in a firm's coverage ratio indicates a better (worse) balance sheet position and less (more) costly access to financial funds, thereby inducing a rise (fall) in the firm's inventories investment.

The results of the effects of interbank rate and interest rate spread are summarized in Tables 3 and 4. Focusing on the interbank rate (columns (3) and (4) of Table 3 ), the $I R$ has coefficients of 0.0480 and of 0.0189 for all firms and large firms, respectively. The corresponding coefficient for small firms is significant and negatively related to inventories investment. In the long run, the change in interbank rate is also statistically relevant. It depicts, by assuming that everything else being constant, that one percent decline in the basis point of interbank rate reduces the inventories investment by two percent to 3.8 percent.

In Table 4, we modify the estimation of equation by substituting the interbank rate by interest rate spread $(S P D)$. This is an interesting exercise, given that interest rate spread has been proved to have a strong influence on macroeconomic variables (Bernanke and Blinder, 1992). We can see that the effects of interest rate spread on inven- tories investment are significant for three different sample categories.

\section{Conclusions}

In this paper, we have estimated an equation for inventory in generalized least square format, augmented by financial variables for different size of firms. To identify the effects of variation in the coverage ratio or in the monetary policy on inventory, we have altered the proxies for monetary policy with interbank rate and interest rate spread. The results have confirmed the existence of a significant link between financial variables and inventory, which is stronger for large firms than small firms. Eventually, one could ask about how changes in financial variables affect aggregate inventories. What we have shown in this study is that the coverage ratio and the monetary policy affect inventories of large firms significantly, but they have weaker effects on other firms. Consequently, the existence of aggregate effects of financial variables on inventories investment ought to depend on whether large firms account for sufficiently large shares of the variation in aggregate inventories investment. 
Ismail \& Bahari-Monetary Policy, Debt and the Cyclical Behavior of Inventories

\section{References}

Asquith, P., R. Gertner, and D. Scharfstein. 1994. Anatomy of financial distress: An examination of junk-bond issuers. The Quarterly Journal of Economics 109: 625 658.

Bernanke, B. S., and A. S. Blinder. 1992. The federal funds rate and the channels of monetary transmission. The American Economic Review 82 (4): 901-921.

Bernanke B. S., and M. Gertler. 1989. Agency costs, net worth, and business fluctuations. The American Economic Review 79 (1):14-31.

Blinder, A. S., and L. J. Maccini. 1991. Taking stock: A A critical assessment of recent research on inventories. Journal of Economic Perspectives 5: 73-96

Calomiris, C. W., and R. G. Hubbard. 1990. Firm heterogeneity, internal finance, and 'credit rationing.' The Economic Journal 100: 90-104.

Chatelain, G., von K. Hernando, and Vermeulen. 2001. Firm investment and monetary policy transmission in the EURO area. Working Paper BANCO DE ESPANA/ DOCUMENTO DE TRABO NO. 0119

Chikan, A., and C. Horvath. 1999. A multi-country analysis of aggregate inventory behaviour. International Journal of Production Economics 59: 1-11.

Chirinko, R., S. Fazzari, and A. Meyer. 1999. How responsive is business capital formation to its user cost? An exploration with micro data. Journal of Public Economic 74: 53-80.

Cooley, Th. F. and V. Quadrini. 1999. Monetary policy and the financial decisions of firms. Http://www.econ.duke.edu/ quadrini/papers/bcpap.pdf. (December 6).

Friedmen, M., and A. J. Schwartz. 1963a. A Monetary History of the United States (19871960). Princeton, New Jersey: Princeton University Press.

Fuerst, T. S. 1992. Liquidity, loanable funds, and real activity. Journal of Monetary Economics 29: 3-24.

Gertler, M. 1992. Financial capacity and output fluctuations in an economy with multiperiod financial relationship. The Review of Economic Studies Limited 59: 455-472.

Gettler, M., and S. Gilchrist. 1994. Monetary policy, business cycles, and the behaviour of smaller manufacturing firms. The Quarterly Journal of Economics CIX: 309-340.

Goldsimth, R. W. 1969. Financial Structure and Development. New Haven, CT: Yale University Press.

Goodfriend, M. 1991. Interest rates and the conduct of monetary policy. In Carnegie, Rochester Conference Series 34: 7-30.

Graham, J. R. 1999. Do personal taxes affect corporate financing decisions? Journal of Public Economics 73 (2): 147-185.

Gurley and Shaw. 1955. Financial aspects of economic development. American Economic Review XLV: 515-538.

Holmstrom, B., and J. Tirole. 1997. Financial intermediation, loanable fund, and the real sector. The Quarterly Journal of Economics CXII (3) (August): 663 - 691. 
Gadjah Mada International Journal of Business, January - April 2007, Vol. 9, No. 1

Kasyap, A., J. C. Stein, and D. W. Wilcox. 1993. Monetary policy and credit conditions: Evidence from the composition of external finance. The American Economic Review 8 (1): 78-98.

Kasyap, A., J.C. Stein, and O. Lamont. 1994. Credit conditions and the cyclical behavior of inventories. Quarterly Journal of Economies 109: 565-592.

King, R. G., and L. Rose. 1993a. Financial and growth: Schumpeter might be right. The Quarterly Journal of Economics 108 (August): 717-727.

King, R. G., and L. Rose. 1993b. Finance, entrepreneurship, and growth. Journal of Monetary Economics 32: 513-542.

Kiyotaki, N., and J. Moore. 1993. Credit cycles. Mimeo. University of Minnesota.

Laurent, R. D. 1988. An interest-rate based indicator of monetary policy. Federal Reverve Bank of Chicago Economic Perpectives.

Leo de Haan, and S. Elmer. 2000. Capital structure, corporate govermance, an monetary policy: Firm-level evidence for the Euro area. Working Paper for Conference of Financial Structure, Bank Behavior, and Monetary Policy in the EMU (5-6 $6^{\text {th }}$ October). Groningen: Unversity of Groningen.

Levine, R., N. Loayza, N., and T. Beck. 2000. Financial intermediation and growth: Causality and causes. Journal of Monetary Economic 46: 31-77.

Levine, R., and S. Zervos. 1998. Stock markets, banks, and economic growth. American Economic Review 88: 537-558.

Lovel, M. 1961. Manufactures' inventories, sale expectations and the acceleration principle. Econometrica 9: 293-314.

Lovel, M. 1996. Macroeconomic implications of S,s versus accelerator finished goods, inventory strategis. International Journal Production Economic 45: 55-64.

MacKie-Mason, J. 1990. Do firms care who provides tehir financing? In R. Glenn Hubbard, ed., Asymmetric Information, Corporate Finance, and Investment. Chicago, IL: University of Chicago: 63-103.

McKinnon, R. I. 1973. Money and Capital in Economic Development. Washington DC: Brooking Institution.

Oliner, S. D., and G. D. Rudebush. 1996. Monetary policy and credit conditions: evidence from the composition of external finance; comment. American Economic Review 86: 300-309.

Romer, D., and C. Romer. 1989. Does monetary policy matter? A new test in the spirit of friedman and Schwartz. Working Paper National Bureau Of Economic Reasearch (May): 2966.

1991. New evidence on the monetary transmission mechanism. Kertas Kerja National Bureau Of Economic Reasearch (Februari): 1520

Roussean, P. L., and P. Wachtel. 1998. Financial intermediation and economic performance: Histrical evidence from five industrialized countries. Journal of Money, Credit and Banking. 30 (4) (November).

Siegfried, N. A. 2000. Microeconomic evidence for a German credit channel. Quantitative Macroeconomic Working Paper Series 1/2000. Hamburg: Hamburg University. 